Seminars, Conferences, Addresses

\title{
Pluralism and Ethnic and Sectarian Diversity in the Arab World
}

\author{
12-16 Jumādō al Äkhir / 26-30 November 1993 \\ International Institute of Islamic Thought \\ Herndon, Virginia
}

This seminar, sponsored jointly by the International Institute of Islamic Thought and the Waqf Fund of the Kuwaiti Ministry of Awqāf, was held at Herndon, Virginia. Twenty-five papers were presented during the seminar's eight sessions, which were attended by scores of Arab Muslim scholars and intellectuals from the United States and abroad, either as primary authors of research papers, commentators, or contributors to the serious and in-depth debate that followed each session.

Issues of democratization and how to deal with ethnic and sectarian diversity in a context of modern society have become topical and central to the political and intellectual debates in the Arab world. During the past few decades, social and political instability has undermined profoundly the prospects for progress and prosperity in the Arab world. Pertinent to this instability was the failure to establish consensual policies and institutions in the post-Ottoman era. Hence, questions relating to "traditional" and "modem," "pan-Islamic" and "nationalist," "absolute" and "relative," and "us" and "others" were raised prominently and discussed during the seminar's five days.

The opening session, chaired by Hisham Altalib (IIIT), consisted of three contributions. The first was that of Khālid al Zir (Kuwaiti Ministry of Awqäf), who focussed on the value of research as a higher value and emphasized the role of waqf in Islamic life. Tāhā J. al 'Alwānī (President, IIIT), spoke on behalf of IIIT and elaborated on the significance of 
intellectual seminars and conferences as instruments for the deliberation of issues and problems faced by the ummah. He pointed to the sensitivity surrounding the seminar's subjects and stressed the intellectual rather than the political approach to these subjects. The third contribution to this session was presented by Khayr al-Din Hasib (President, Centre for Arab Unity Studies) on behalf of the participants. He dwelt on the indispensibility of democracy and pluralism to the Arabs' search for an outlet from the present political and civilizational crises. He also underscored the relevance of a continuous Arab nationalist-Islamic dialogue in order to arrive at a common understanding between the Arab elites.

Works of the seminar began in earnest after the opening session. The first two papers were those of 'AbdulHamīd AbūSulaymān (President, International Islamic University, Selangor, Malaysia) and Tāhā J. al 'Alwāni. The main theme of AbūSulaymān's paper was the need for a methodological approach to the issues of pluralism and democracy. He deplored dominant methods of analysis as either imbibed with foreign values and influences or as costly attempts to perpetuate irrelevant ancient models. He brought attention to the necessity of recognizing and differentiating between what is immutable and what is changeable as regards Islamic norms and values. Inasmuch as he tried to explain the unhealthy conditions of the ummah today, he called for the development of a humane non-nationalist Muslim intellectual discourse.

Several fundamental points emerged from al 'Alwān̄’s paper. One is related to the ability of the historical Islamic model to establish unity in a framework of diversity. The other concerned the inseparable attachment between the Arab mind and Islam, to the degree that without the Islamic intellectual space, al 'Alwānī affirmed, the contemporary Arab mind would live in a vacuum. He also pursued an Islamic epistemological approach to elaborate on the problem of pluralism, making the science of ușul al fiqh his frame of reference. Explaining the two major Islamic schools of thought on the question of truth and knowledge, al 'Alwānī endorsed implicitly the school that considers truth relative and multiple.

In an important contribution to the seminar, Mona Abul-Fadl (Westem Thought Project, IIIT) stated that, epistemologically, the question of pluralism is universal and not a problem of Islamic thought alone. In her view, the western paradigm of pluralism is deconstructive rather than constructive. However, there are still many obstacles that have to be surmounted before Muslims can deal effectively with sources of Islamic theorization in order to construct a transcendental paradigm.

In a short but profound commentary, Radwan al-Sayyid (Editor, AlIjtihād and Lecturer, The Lebanese University) attempted to reveal some historical Islamic traditions regarding questions of unity and pluralism. 
His approach was preoccupied with what he identified as the dialectic between the text and reality that produced the historical experience of the ummah. Similar to al 'Alwānī's emphasis, al-Sayyid pointed to the Musāwabah school of thought, which accepted the relativity and multiplicity of truth. He also elaborated on the Islamic tradition of rejecting violence and dissent and supported his case with evidence of the attitudes of the Companions and jurists toward al fitnah al kubrā and the controversy surrounding the creation of the Qur'an.

Many other papers dealt with the historical and contemporary analysis of specific issues or geographical regions. Khālis Jalabī, for example, made the case for nonviolence. Hamdī "Abd al Rahmān (University of Cairo) presented an extensive survey of "Issues of Pluralism in Islamic Africa." Jalāl Mu'āwad dealt with "Islam and Pluralism in Turkey: 19821991." Khālid al "Awamlah discussed "The Iranian Experiement in Respect to the State and Political Pluralism." "Abd al Khāliq (University of Cairo) and al Sammāk presented detailed studies on the "Political Dimensions of the Concept of Pluralism" and "The Problematic Relations between Minorities and Foreign Powers," respectively. "Abd al Khāliq, in particular, attempted to construct an Islamic model for the modern "quasination-state" as a balanced relationship between the universal Islamic concept of ummah and the reality of "regional states." The contributions of Muhammad 'Ammārah, Basheer Nafi, and Wajīh Kawtharānī were focussed largely on the historical context and consequences of modernization, the collapse of the ancient sultanic system, and the undermining of traditional societal institutions.

As usual, the seminar raised many significant questions and opened a new door for scores of Muslim intellectuals and academics to become more familiar and more associated with issues that are determining, to an increasingly large degree, the direction toward which the Muslim world is now turning.

Basheer Nafi International Institute of Islamic Thought Herndon, Virginia 